\title{
Meskhetian (Ahiska) Turks in Turkey and Their Perception of Spatial Belonging
}

\author{
Zerrin Toprak Karaman1, Damla Mursül² \\ ${ }^{1}$ Department of Public Administration, Dokuz Eylül University, İzmir, Turkey \\ ${ }^{2}$ Department of Political Science and Public Administration, Nuh Naci Yazgan University, Kayseri, Turkey \\ Email: zerrin.toprak@deu.edu.tr, dkabakusak@nny.edu.tr
}

How to cite this paper: Karaman, Z.T. and Mursül, D. (2018) Meskhetian (Ahiska) Turks in Turkey and Their Perception of Spatial Belonging. Open Journal of Social Sciences, 6, 88-103.

https://doi.org/10.4236/jss.2018.612009

Received: November 15, 2018

Accepted: December 15, 2018

Published: December 18, 2018

Copyright ( 92018 by authors and Scientific Research Publishing Inc. This work is licensed under the Creative Commons Attribution International License (CC BY 4.0).

http://creativecommons.org/licenses/by/4.0/

(c) (i) Open Access

\begin{abstract}
In its various aspects, the subject of "belonging" has been an important fundamental indicator in terms of understanding "social belonging relations" throughout the history of mankind. This study focuses on the Meskhetian Turks who have immigrated to Turkey since 1992. Using the selected sample below, it considers the Meskhetian Turks' choice of a preferred motherland, Turkey or their own Meskhetian Territories with regard to social belonging. The research also questions the role of Turkish Governments during the period 1992-2017 who as decision makers in matters of "immigration administration" "encouraged" or "discouraged" the Meskhetian Turks to enter in Turkey. In addition, the level of public awareness drawn by the Meskhetian Turks' recently increasing rates of arrival in Turkey along with the subject of their social adaption to local public life will be questioned through in depth interviews. Moreover, on a broader level, the emotions of the Meskhetian Turks towards spatial belonging will be scrutinized. And in the final analysis, the content of this paper examines the general question of "motherland" belonging, which is claimed to exist amongst the Meskhetian Turks both towards Turkey and the Meskhetian territories.
\end{abstract}

\section{Keywords}

Identity Belonging, Meskhetian Turks, Immigration Administration, Social Belonging, Spatial Belonging

\section{Introduction}

More and more people have been leaving their current regions and crossing from one country to another either legally or illegally in recent years for reasons of political threats, natural disasters caused by climatic changes or the economic dynamics of globalization. These migrations do not constitute small group mo- 
bility limited merely to family and blood ties. Large numbers of ethnic groups are presently involved in external immigration or migration.

According to most researchers, globalization has led to the transformation of the identities of national territories or specific regions regarding their historical symbolism. However, in the migrations resulting from political causes, settlers begin to react when a danger arises, or a threat is perceived, against individual rights and freedoms. In general, countries tend to reject those communities that have settled in their own territories because they consider them "a threat against their economy and welfare states, cultural and religious assets, social orders, and political stability" for reasons which are similar to those of the groups desiring to settle in their countries. In this study, the case specifically evaluates "belonging" to the Meskhetian Turks that have immigrated to Turkey following social and political/administrative "rejection" in their own territories [1].

This study, also highlights the terminology used to determine the direction of social belonging. Even though "territorial belonging" and the words "home", "native" and "mother" can may appear synonymous when explaining the population mobility in the territories. Since about the $4^{\text {st }}$ century A.D. semantic differences of this word have occurred for Turks who migrated from Central Asia. Although "homeland": (a person's native-land) and "motherland" (a person's native country) are used interchangeably in dictionaries (e.g. Oxford Dictionary), the word "homeland" is used in this study as the place which provides a person with opportunities for accommodation, living, and sound access to the quality of life standards and which is acknowledged as a homeland. On the other hand, "motherland" is used for "the ancestral territories" for which a person has emotional relationships and that is acknowledged as the first homeland. The expression "The motherland of Turks is Central Asia", widely used in Turkish history education, accentuates this usage. While the Turks living in Turkey evaluate Central Asia as the "motherland", the fact that Turkey is a country in which those of Turkish origin can easily take refuge due to its political affiliations and shared has caused the Turks living outside Turkey to define Turkey as the "motherland".

The study consists of two main sections. The first section relates to Meskhetian Turks' sense of belonging. The content of this section is based on the relevant data in Damla Mursül's recently published PhD dissertation [2]" and supported by the data from questionnaires carried out with a sample of 180 Meskhetian Turks in 2016 and 2017. The second section concerns the views of Turkish citizens regarding the Meskhetian Turks. Face-to-face questionnaires were carried out with 173 university students, (via the Web: http://afetyonetimi.deu.edu.tr/) and 105 Turks. In addition to this, in-depth interviews with Meskhetian Turks carried out in January, February, and March 2018 provide recent findings, which are independent of the $\mathrm{PhD}$ dissertation.

\section{History of Meskhetian Turks}

Meskhetian Turks are a group of Turkish-speaking people from Meskhetia 
which borders Turkey. The traditional native-land of Meskheti (Ahıska) is in south-western Georgia to the south of the Meskhetian mountain ridge. In the past, during the periods of the Ottoman Empire, Czarist Russia, and the Union of Soviet Socialist Republics (until 1944) Meskhetian Turks lived in the Meskhetia-Cahaveti region. Today, however, they live in Azerbaijan, Uzbekistan, Kazakhstan, Kyrgyzstan, Russia, Georgia, the Ukraine, Turkey, and the USA [3]. The World Union of Meskhetian Turks (DATUB) also includes the Turkish Republic of Northern Cyprus in these countries. Their total number in all countries is around $350-400$ thousand [4] or 430 - 440 thousand [5]. The number of Meskhetian Turks living in Turkey is predicted to be around 35 thousand [3]. Nevertheless, it should be expressed that these above-mentioned figures are only approximate calculations [6].

Under Stalin's rule, Meskhetian Turks were declared "Enemies of the Soviet People" and exiled in 1944 from the territories in which they lived, i.e. from the Meskhetian region that they related to in the sense of "belonging as a homeland" (territorial national identity, homeland) [7]. Naturally, this was a traumatic situation. Since they had fought together with Russian soldiers against Germans in order to protect "their homeland" where they had been living since the 700 s and were recognized as Meskhetians. However, it is a general political strategy not to keep related communities on both sides of a border for military reasons. On the other hand, the presence of related communities on both sides of a border can be a good reason to develop neighboring relations.

Today the Meskhetian Turks who have settled outside Turkey lack their own autonomous administrative unit and any official recognition. In other words, Meskhetian Turks, who can also be defined as an ethnically heterogeneous and a stateless minority, have not been able to build a nation on their own territories nor have they been able to gather under a political organization. This has caused Meskhetian Turks to be evaluated as "stateless". It is thought that being stateless makes Meskhetian Turks politically unprotected and causes them to be excluded by other peoples [6].

The cultural and religious commonalities between Turks in Turkey and the Meskhetian Turks who were of Turkish origin and who adopted this ethnic identity facilitated their peaceful coexistence in Turkey. Therefore, Meskhetian Turks were not evaluated as "foreigners" in the society or the public domain in Turkey.

Nevertheless, the same friendly acceptance is not shown in the political climate in the Meskhetian region. "Conflicting Values" such as different religion and language might be influential factors. The evaluations of this case by the Meskhetian Turks who were suddenly confronted with "political rejection" in their homeland territories are interpreted below.

\section{Being Immigrants of Turkish Origin in Turkey}

In Turkey, the legal terminology defines an immigrant as "one who is of Turkish 
origin and connected with the Turkish culture, has come to Turkey either singly or collectively in order to settle, and is admitted in accordance with this law" [8] in terms of Settlement Law No. 5543 dated 2006 [9]. Meskhetian Turks therefore constitute a privileged group as compared with other ethnic groups and were identified as "immigrants" in their status before acquiring Turkish citizenship.

The factor of being of Turkish origin stands out in the legal regulations and shows that the social and cultural structures of immigrants are important reasons for admission in terms of the harmony of the society and national security accordingly [10]. Nevertheless, in Turkey, the immigration movements of Meskhetian Turks fit the provisions of Law No. 3835 as being forced migration and were implemented within an "annual quota". However, their preference for immigration to Turkey cannot be associated with access to economically better living conditions (March 2018, Interviews at Sarıkaya District and in the Toprakpinar Village, Yozgat).

Examination of whether the Meskhetian Turks see themselves as "asylum seekers" [11] in Turkey in terms of the legal provisions (Settlement Law No. 5543 and Law No. 3835) to which they are subjected is relevant to this study. The reason for such a perception results from a lack of political support from the Turkish Government. According to data based on Damla Mursül's PhD dissertation; there anxiety is clearly shown in the questionnaire completed by 180 of Meskhetian Turks in Turkey, $21.1 \%$ of the respondents (38 people) mentioned that the state provided little support, while $20.6 \%$ of them ( 37 people) stated that it provided no support. Although $(48.3 \%, 87$ people) were undecided the rate of those who thought that adequate support was provided was only $10 \%$ (18 people).

The failure to implement the provision of Law No. 3835 dated 1992 along with the higher priority suddenly given to the influx of asylum seekers from Syria, are obvious reasons for the extremely concerned emotions of the Meskhetian Turks (from the interviews in 2016-2017).

Going back to the period of the Union of Soviet Socialist Republics (USSR), a special settlement policy which removed the restrictions [12] on Meskhetian Turks, was issued in 1956. With this decree, Meskhetian Turks were free to settle in any place within the USSR other than Meskheti. However, Meskheti was the homeland territory (territorial identity, homeland) [13] for Meskhetian Turks and they wanted to return there. Especially for most of the elderly, the homeland was Meskheti, once a region affiliated to the Ottoman Empire.

Being of historic significance, this region remained within the Georgian territories after the disintegration of the USSR in 1991. For the Meskhetian Turks with close bonds with their villages, the homeland was not Georgia but merely the villages where they lived. However, according to the studies, for the Meskhetian Turks who were born in Uzbekistan and other Central Asian states following the exile of 1944, the Meskhetian territories represent "belonging" only as 
"an emotional bond". On the other hand, the territories of the State of the Republic of Turkey have a political meaning for these groups [14].

The in-depth interviews also verify these evaluations. Those Meskhetian Turks who stated that they maintained the cultural unity in the Sarkaya district of Yozgat province added that Meskheti was no more the homeland for them. A good indicator to this end is whether they have any properties in Meskheti. Likewise, the interviews contain such sentences as "I have no investment in Meskheti. We do not need to make any investments because we do not want to settle there permanently. We have made investments in these territories (Turkey). With my siblings, we have built this house, purchased buses, and operated them for years. There are a few more months for my retirement etc" (March 2018, Interviews at Sarıkaya district, Yozgat).

According to these above-mentioned evaluations, "Meskheti" is no more a homeland territory for those Meskhetian Turks who have arrived and settled in Turkey for good, although they were born in Meskheti. Since "no citizenship bond has formed" for those Meskhetian Turks who were born and live outside Meskheti as well as outside the territories of the Republic of Turkey, no "Territorial National Identity" has been provided. For these groups, Turkey is only a country (motherland) which creates confidence similar to the case in which a child in difficulty runs to his/her mother.

Moreover, identities have become more likened than ever in modern societies. A measure of the freedoms of people is described to being a "tourist" [15]. Being able to go from one country to another freely and having quality of life standards is a modern and democratic privilege. This above-mentioned population mobility is distinguished from "voluntary and involuntary" migrations. Meskhetian Turks also desire to live in Meskheti and act as free tourists. However, this hope of theirs has died over time.

\section{Can Meskhetian Turks Be Evaluated within the Theory of Liquid Modernity?}

As the same time as the country/countries that the Meskhetian Turks left, were indeed forced to leave, and which did not offer much confidence for them in terms of the quality of life implying "it will be good if you go", the political environment of the Turkish Government was implying "it will be good if you come". Does a type of individual who avoids forming permanent social bonds that are binding and rigid and that introduce liabilities and responsibilities and who accordingly displays a more flexible and undecided attitude by departing from displaying fixed and preserved features in this environment-explained by Zygmunt Bauman with the concept of liquid modernity-apply to Meskhetian Turks? According to Bauman, this individual set-up is available not only in love relationships but also in such social and economic relationships of an individual as friendship, neighborhood, family, and employment in the public domain. The Meskhetian Turks who have arrived and settled in Turkey are not included in this theory but have integrated comfortably into the society. 
Whereas Meskhetian Turks were off "foreigner" status before they acquired citizenship, they are not evaluated as foreigners in the society due to the commonality of origins. They are accepted as "we" in Turkey.

The coexistence of "we" (friendship) refers to the "sociocultural" similarities which lead to mutual trust and solidarity among the group members with.whom they feel attachment. Nevertheless, in terms of the relations with the Georgian government, "maintaining one's settlement in Georgia" is associated with accepting "assimilation". In this case, being able to abide in the Meskhetian region, in a sense, gives rise to alienation from national belonging. This is supported in the in-depth interviews. The following evaluations were made regarding those who have been able to maintain their settlement in Meskheti by the Meskhetian Turks who migrated to Turkey.

"Those who live in Meskheti have made a concession from either their Turkishness or their being Muslims. They do not come here. On the other hand, the Meskhetian Turks living in different countries of the world maintain our same traditions and customs there as well. Maybe they have better living conditions there, but there may be elderly people among them who want to come to Turkey. The new generation, particularly those who live in the USA, do not want to come to Turkey" (March 2018, Interviews at Sarıkaya district, Yozgat).

In Turkey, however, those who had an "immigrant" identity within the status of being of Turkish origin [16] before acquiring the citizenship status doubtlessly differ from the immigrants in the "refugee-foreigner" status. Independently of the territories that they came from, being of Turkish origin consolidates their visibility in the "public domain" in terms of the unity of cultural and ethnic commonalities.

In the final analysis, no matter which geographical area immigrants come from, a commonality is formed in terms of social belonging in the "social memory" in Turkey, as in the examples of the Balkans and Meskheti. Likewise, in the studies on the asylum seekers coming through irregular external migration, settled citizens (70\%) stated that they looked for a "cultural bond" rather than the commonality of religious brotherhood and some added that they perceived the migrations coming particularly from regions like Syria as a "threat" [17]. Unlike their altitude towards the Meskhetian Turks have been able to develop social bonds. As also stated above, regardless of whether one was born in the Meskhetian region or outside Meskheti, Turkey is now evaluated as a "homeland" associated with the "territorial national identity" in terms of those who have come to Turkey in order to settle permanently. Thus, the immigrant Meskhetian Turks desire to acquire Turkish citizen status rapidly. Such a view is substantiated in the questionnaires below.

One person commented, "There are only about 600 thousand Meskhetian Turks worldwide, a very small number. There won't be any problems if Turkey naturalizes all of us. We are now talking about 3 million Syrians here. These siblings of yours, however, are already professionals and educated. Why don't you naturalize us?' (August 2016, the In-depth Interview in Antalya, etc.) 
No tendency to consider the Meskhetian Turks a distinct social group occurred in responses of the resident population in Turkey either. It is also possible to see this matter from the results of the face-to-face questionnaires carried out with the young groups of university students in Turkey as well as those via the Internet with the adults who were predominant members of nongovernmental organizations. We will return to this issue later (See Questionnaires, the settled Turks in Turkey).

\section{Preference for Belonging among the Meskhetian Turks Who Immigrated to Turkey}

The information under this title with respect to "the preference for belonging" among the Meskhetian Turks who immigrated to Turkey was based on the PhD dissertation. A profile of the Mesketian Turk participants shows that $7 \%$ of the respondents (3 people) were born in Turkey of the remaining respondents $35 \%$ were born in Kazakhstan, 32.2\% in Uzbekistan, 14.4\% in Azerbaijan, and the others are lower rate (in Russia, Kyrgyzstan, Georgia and Ukraine). $61.7 \%$ of respondences are male, while $38.3 \%$ are female. $8.3 \%$ of the respondents are secondary school graduates; $42.2 \%$ of them are high school graduates; $38.3 \%$ of them are university graduates; and $7.2 \%$ of them have received postgraduate education. The overwhelming majority of Meskhetian Turks are at least high school graduates.

According to the information obtained in Table 1, 62.8\% of the respondents are in the age group of 18 - 30 years, $28.3 \%$ of them in the age group of $31-50$ years, and $8.9 \%$ of them in the age group of 51 years and over. It can be seen that the age group with the highest participation is the young Meskhetian Turks.

In Table 2, it was intended to determine the forms of expressions that the Meskhetian Turks used to identify themselves through a multiple-choice question. Taking ethnic consciousness rather than ethnic origin as the determining factor [18], the way the Meskhetian Turks who made up the questionnaire sample adopted the Turkish culture and the belonging of being a Turk was examined.

According to Table 2, the choice of defining oneself as a "Meskhetian Turk" ranked highest (28.9\%), followed by a Muslim Turk (8.3\%) and a Turk (7.2\%). Only 1 Meskhetian Turk preferred identifying himself just as a Muslim. While $2.8 \%$ of the respondents did not find such identifications necessary, $13.3 \%$ and $37.8 \%$ of the respondents accepted all or any options (as a Turk/Muslim/Meskhetian Turk/Muslim Turk). This shows the tendency of a group of immigrants to use their identity belonging together with their territorial belonging. According to this data, although the Meskhetian Territories (homelands) maintain a bond for some groups, they have lost this connection of being a "homeland" for others.

$A$ cross-examination to evaluate the relationship between the migration period and age produced the following result,

Of those people from all age groups, who arrived during the period 
1992-2017, 2\% identify themselves as “a Turk, a Muslim, a Meskhetian Turk, and a Muslim Turk" and they definitely want to return to Meskheti. A further $25 \%$ want to return to Meskheti on condition that they obtain a political status there. For these groups Turkish belonging appears weak.

However, those who arrived during the period 2011-2017 are all aged 18-30 years. $30 \%$ of this group identify themselves only as Meskhetian Turks but have no desire to return to Meskheti. Those who arrived in the previous periods (1992-2011) are from all age groups and 70\% of them identify themselves with more than one identity such as "a Turk, a Muslim, a Meskhetian Turk, and a Muslim Turk" but have no desire to return to Meskheti. The reasons for their migration from Meskheti are summarized in Table 3.

According to Table 3, there is a high level of the Authority's mistrust of its Turkish neighbors and a fear of ethnic Muslim-Turkish society in Meskheti. In other words, their exile from Meskheti is a politically and administratively directed "forced and mass" migration.

According to a further survey, regarding Turkish citizenship, (43.9\%) of the total group already have Turkish citizenship, they were eager to get it then; $53.9 \%$ (in all) stated that they desire to become Turkish citizens. Only 4 Meskhetian Turks (2.2\% of them) stated that they did not desire to become Turkish citizens. For the immigrant groups that arrived in Turkey therefore the country alternates between a "motherland" and a "homeland". Some two to three generations later, Turkey will probably be evaluated within the "homeland belonging" for the Meskhetian Turks who have adopted a permanent life there.

Table 1. Distribution of ages of Meskhetian Turks.

\begin{tabular}{ccccc}
\hline & Frequency & Percent & Valid Percent & Cumulative Percent \\
\hline $18-30$ years & 113 & 62.8 & 62.8 & 62.8 \\
$31-50$ years & 51 & 28.3 & 28.3 & 91.1 \\
51 years and over & 16 & 8.9 & 8.9 & 100.0 \\
Total & 180 & 100.0 & 100.0 & \\
\hline
\end{tabular}

Table 2. The way the Meskhetian Turks identified themselves.

\begin{tabular}{ccccc}
\hline & Frequency & Percent & Valid Percent & Cumulative Percent \\
\hline I identify myself as a Turk & 13 & 7.2 & 7.2 & 7.2 \\
I identify myself as a Muslim & 1 & 0.6 & 0.6 & 7.8 \\
I identify myself as a Meskhetian Turk & 52 & 28.9 & 28.9 & 36.7 \\
I identify myself as a Muslim Turk & 15 & 8.3 & 8.3 & 45.0 \\
I don't find such identifications necessary & 5 & 2.8 & 2.8 & 47.8 \\
All (the first 4 options) & 24 & 13.3 & 13.3 & 61.1 \\
More than one choice & 68 & 37.8 & 37.8 & 98.9 \\
Other & 2 & 1.1 & 1.1 & 100.0 \\
Total & 180 & 100.0 & 100.0 & \\
\hline
\end{tabular}


Table 3. The reason for being exiled from Meskheti.

\begin{tabular}{ccccc}
\hline & Frequency & Percent & Valid Percent & $\begin{array}{c}\text { Cumulative } \\
\text { Percent }\end{array}$ \\
\hline $\begin{array}{c}\text { Having a Muslim cultural tradition } \\
\text { The authority's mistrust of the }\end{array}$ & 6 & 3.3 & 3.3 & 3.3 \\
$\begin{array}{c}\text { Muslim-Turkish society on the border } \\
\begin{array}{c}\text { The authority's mistrust of the Turkish } \\
\text { society on the border }\end{array}\end{array}$ & 9 & 21.1 & 21.1 & 24.4 \\
$\begin{array}{c}\text { Turkish refusal to assimilate the society } \\
\text { on the border }\end{array}$ & 12 & 5.0 & 5.0 & 29.4 \\
$\begin{array}{c}\text { Having the Turkish culture and } \\
\text { tradition }\end{array}$ & 22 & 12.3 & 12.3 & 48.4 \\
$\quad \begin{array}{c}\text { Committing treason } \\
\text { Multiple reasons } \\
\text { Total }\end{array}$ & 12 & 6.6 & 6.7 & 55.0 \\
$\quad 81$ & 45.0 & 45.0 & 100.0 \\
\hline & 180 & 100.0 & 100.0 & \\
\hline
\end{tabular}

Likewise, the research on the migration process of Meskhetian Turks supports this view. The process of migration of Meskhetian Turks to Turkey should be addressed at two stages. The first stage refers to the migrations performed from the commencement of the control of Meskheti by the Russian administration during the Russo-Ottoman War up until 1944, whereas the second stage refers to the migrations from a wide range of countries to Turkey in and after the process of disintegration of the USSR. The tendency to return to Turkey becomes more dominant over time owing to the negative reaction of the Georgian society in Meskheti [19]. According to Pentikainen and Trier, those who came in the first stage constitute the group that has fused with the society and that is not known as Meskhetian in the society. On the other hand, the other group, which makes up the majority, is known as Meskhetian in the places where they live [20].

Although the Turks in Turkey have seemingly limited knowledge regarding the Meskhetian Turks, their common Turkish origin is enough to ensure their preliminary acceptance which in turn creates a positive impact on social integration. It does not leave a need for the Meskhetian Turks to build unique social networks as a distinct group (March 2018, Interviews at Sarıkaya district, Yozgat). However, as a result of their lack of a political union, little is known of their historical background which leaves them politically alone in Turkey.

\subsection{Awareness of Meskhetian Turks by Turkish Citizens in Turkey}

The inquiry based on the questionnaires in this section was carried out by the method of face-to-face questionnaires with 173 students between 20 - 25 years of age all in higher education in İzmir in January 2018 and broader-based online questionnaires responded to by 105 people (unfortunately the exact number of all Meskhetian Turks living in Turkey, has not been shared by the institutions). 


\subsubsection{University Students' Responses}

As seen in Table 4, those who are Turkish citizens and of Turkish origin make up $86.1 \%$, of the study while those of Turkish citizens who are not of Turkish origin $13.9 \%$. No statistical deviation was detected in the responses by the Turkish citizens who were not of Turkish origin compared with those of Turkish origin.

Of the respondents, $46.2 \%$ were female and $53.8 \%$ were male according to Table 5.

As seen in Table 6, whilst $11.6 \%$ of the students who responded to the questionnaire had a friend and/or a relation who was a Meskhetian Turk, the majority (88.4\%) had none.

According to Table 7, only $33.5 \%$ of the respondents knew of the geographical region called Meskheti whereas a larger group of $64.7 \%$ responded to this question by saying that they "did not know" where Meskheti was.

Table 8 tests the knowledge of those who claimed to know it. While those who were able to associate Meskheti with the Georgian region was $41.7 \%$, those who stated that it was a place in Central Asia and in Siberia was $23.3 \%$ and those who stated that it was in Azerbaijan 11.7\%. It can be seen that the majority of the respondents did not know the geographical location of Meskheti.

According to Table 9, concluded on Turkish respondents; declared that the Internet and TV provided most awareness of Meskhetian Turks, $33.7 \%$ and $22.1 \%$, respectively.

Most of the Turkish citizens (76.9\%), responded to the question about forming friendships easily with Meskhetian Turks by saying "I have no idea" in Table 10. Such a response is probably because they do not know whether their friends are Meskhetian or because they do not find it necessary to know due to faith and cultural commonalities. This high rate of response reflects the fact that Meskhetian Turks do not have different and distinct visibility in the public life. The cultural structure, the unity of origins and the physical similarities have not created any visual or behavioral differences. As also stated in the above-mentioned lines, the common ethnic belonging with the majority of the settlers in Turkey $\boldsymbol{e x}_{\boldsymbol{x}}$ cludes Meskhetian Turks from the theory of "liquid modernity". In other words, Meskhetian Turks do not pose themselves in a distinct place in the society.

According to the cumulative percent of Table 11; few people, $22.5 \%$, see the immigration is an opportunity.

To the question on the determination of whether Turkey had any state policy on Meskhetian Turks, $83.2 \%$ responded by saying "I Have No Idea". $6.9 \%$ stated that it had a state policy, while those who stated that it had no state policy was 9.8\% according to Table 12 . This issue essentially indicates that no lobbying was performed to protect the political interests of Meskhetian Turks abroad and that there was no visible structuring which drew the attention of the settlers in Turkey or which encouraged or stimulated them to do so.

Table 13, evaluates the awareness of the Meskhetian Turks rights (e.g. citi- 
zenship and participation in the working life) in Turkey, compared those of Turkish immigrants from the Balkans. $79.8 \%$ of the respondents admitted to having no idea. $13.9 \%$ believed them to have equal rights to Balkan immigrants while $6.4 \%$ thought they did not. A similar inquiry was carried out for Crimean Turks. An evaluation of this issue is provided below in Table 14 with similar results.

Table 4. Respondents' citizenship status.

\begin{tabular}{ccccc}
\hline & Frequency & Percent & Valid Percent & Cumulative Percent \\
\hline $\begin{array}{c}\text { I am a Turkish citizen } \\
\text { and of Turkish origin }\end{array}$ & 149 & 86.1 & 86.1 & 86.1 \\
$\begin{array}{c}\text { I am a Turkish citizen } \\
\text { but not of Turkish origin }\end{array}$ & 24 & 13.9 & 13.9 & 100.0 \\
Total & 173 & 100.0 & 100.0 & \\
\hline
\end{tabular}

Table 5. Gender.

\begin{tabular}{ccccc}
\hline & Frequency & Percent & Valid Percent & Cumulative Percent \\
\hline Female & 80 & 46.2 & 46.2 & 46.2 \\
Male & 93 & 53.8 & 53.8 & 100.0 \\
Total & 173 & 100.0 & 100.0 & \\
\hline
\end{tabular}

Table 6. Dou you have friends and/or relations who are Meskhetian Turks.

\begin{tabular}{ccccc}
\hline & Frequency & Percent & Valid Percent & Cumulative Percent \\
\hline Yes & 20 & 11.6 & 11.6 & 11.6 \\
No & 153 & 88.4 & 88.4 & 100.0 \\
Total & 173 & 100.0 & 100.0 & \\
\hline
\end{tabular}

Table 7. Awareness of the fact that Meskhetian Turks lived in a geographical area called "Meskheti".

\begin{tabular}{ccccc}
\hline & Frequency & Percent & Valid Percent & Cumulative Percent \\
\hline Yes & 58 & 33.5 & 33.5 & 33.5 \\
No & 112 & 64.7 & 64.7 & 98.3 \\
Other & 3 & 1.7 & 1.7 & 100.0 \\
Total & 173 & 100.0 & 100.0 & \\
\hline
\end{tabular}

Table 8. Those who knew the geographical location of the Meskhetian Region.

\begin{tabular}{ccccc}
\hline & Frequency & Percent & Valid Percent & Cumulative Percent \\
\hline A place in Central Asia & 14 & 8.1 & 23.3 & 23.3 \\
South-western Region of Georgia & 25 & 14.5 & 41.7 & 65.0 \\
Southern Region of Azerbaijan & 7 & 4.0 & 11.7 & 76.7 \\
Southern Siberian Region & 14 & 8.1 & 23.3 & 100.0 \\
Total & 60 & 34.7 & 100.0 & \\
No answer & 53 & 65.3 & & \\
Total & 173 & 100.0 & & \\
\hline
\end{tabular}


Table 9. Their Means of being informed about Meskhetian Turks.

\begin{tabular}{ccccc}
\hline & Frequency & Percent & Valid Percent & Cumulative Percent \\
\hline Education & 12 & 6.9 & 14.0 & 14.0 \\
The Internet & 29 & 16.8 & 33.7 & 47.7 \\
TV & 19 & 11.0 & 22.1 & 69.8 \\
Written and Visual Media & 12 & 6.9 & 14.0 & 83.7 \\
My Friends & 11 & 6.4 & 12.8 & 96.5 \\
Other & 3 & 1.7 & 3.5 & 100.0 \\
Total & 86 & 49.7 & 100.0 & \\
Missing & 87 & 50.3 & & \\
Total & 173 & 100.0 & & \\
\hline
\end{tabular}

Table 10. Is it easy to form friendships with Meskhetian Turks?

\begin{tabular}{ccccc}
\hline & Frequency & Percent & Valid Percent & Cumulative Percent \\
\hline Yes & 39 & 22.5 & 22.5 & 22.5 \\
No & 1 & 0.6 & 0.6 & 23.1 \\
I Have No Idea & 133 & 76.9 & 76.9 & 100.0 \\
Total & 173 & 100.0 & 100.0 & \\
\hline
\end{tabular}

Table 11. Evaluation of mass immigration of Meskhetian Turks to Turkey.

\begin{tabular}{ccccc}
\hline & Frequency & Percent & Valid Percent & $\begin{array}{c}\text { Cumulative } \\
\text { Percent }\end{array}$ \\
\hline $\begin{array}{c}\text { I evaluate their arrival in } \\
\text { Turkey as an opportunity }\end{array}$ & 39 & 22.5 & 22.5 & 22.5 \\
$\begin{array}{c}\text { I do not evaluate their arrival in } \\
\text { Turkey as an opportunity }\end{array}$ & 31 & 17.9 & 17.9 & 40.5 \\
$\begin{array}{c}\text { I Have No Idea } \\
\text { Total }\end{array}$ & 103 & 59.5 & 59.5 & 100.0 \\
\hline
\end{tabular}

Table 12. Is there a state policy on Meskhetian Turks in Turkey?

\begin{tabular}{ccccc}
\hline & Frequency & Percent & Valid Percent & Cumulative Percent \\
\hline Yes & 12 & 6.9 & 6.9 & 6.9 \\
No & 17 & 9.8 & 9.8 & 16.8 \\
I Have No Idea & 144 & 83.2 & 83.2 & 100.0 \\
Total & 173 & 100.0 & 100.0 & \\
\hline
\end{tabular}

Table 13. Do you think Meskhetian Turks in Turkey can access the same rights as Turkish immigrants from the Balkans?

\begin{tabular}{ccccc}
\hline & Frequency & Percent & Valid Percent & Cumulative Percent \\
\hline Yes & 24 & 13.9 & 13.9 & 13.9 \\
No & 11 & 6.4 & 6.4 & 20.2 \\
I Have No Idea & 138 & 79.8 & 79.8 & 100.0 \\
Total & 173 & 100.0 & 100.0 & \\
\hline
\end{tabular}


Table 14. Do you think the Meskhetian Turks in Turkey can access the same rights as Turkish immigrants who came from the Crimea?

\begin{tabular}{ccccc}
\hline & Frequency & Percent & Valid Percent & Cumulative Percent \\
\hline Yes & 23 & 13.3 & 13.3 & 13.3 \\
No & 5 & 2.9 & 2.9 & 16.2 \\
I Have No Idea & 145 & 83.8 & 83.8 & 100.0 \\
Total & 173 & 100.0 & 100.0 & \\
\hline
\end{tabular}

\subsubsection{Broad-Based Online Responses}

The data given below shows the responses given by 105 members of the general public to three similar questions;

- Are you aware of the migration of Meskhetian Turks to Turkey?

Yes: $55.2 \%$ No: $44.8 \%$

- Are Meskhetian Turks politically oppressed in Meskheti?

Yes: $30.5 \%$ No Idea: $69.5 \%$

- Do you follow the developments about the state policy on Meskhetian Turks?

Yes: $12.4 \%$ No: $48.6 \%$ No Idea: $39.0 \%$

In general evaluating the issue, it can be clearly seen that there is a distinct lack of knowledge of the historical background of the Meskhetian Turks as well as details of their immigration to Turkey and their access to political and social rights. This indifference predominating amongst the general public results from the unavailability of comprehensive information on Meskhetian Turks in the routine history courses at primary, secondary and high school education levels. However despite the availability of written information on the historical background of Crimean Turks and Balkan Turks, younger or the middle-aged generations are not aware of the details today.

\section{Conclusions and Evaluation}

The present study to determine the perception of belonging by the Meskhetian Turks who immigrated to Turkey since 1992 was based on questionnaires and in-depth interviews with members of this group. Additionally, the awareness of the problems of Meskhetian Turks by members of the Turkish public was also examined. The purpose of this inquiry was to find out whether there was strong public support to strengthen the political position of Meskhetian Turks in Meskheti.

Those Meskhetian Turks who are of Turkish origin and who have adopted this ethnic identity have been socially and administratively accepted in Turkey, since their immigration. The presence of cultural and religious commonalities with the settled people is an essential element in social integration.

Some of the Meskhetian Turks who have more recently come to Turkey (since 2011) tend to use their ethnic identity together with their territorial/geographical identity in order to feel a sense of belonging. Even though essentially they did 
not come willingly, the continuation of the relations with kinship in the territories they left enables belonging. For these groups, the Meskhetian territories have remained embedded in their identities as a "homeland". Their identification of themselves as Meskhetian Turks verifies this opinion. Nevertheless, the opinion that the Meskhetian territories only create an emotional bond is widespread among the groups with a longer immigration history. Therefore, the Meskhetian territories may now be evaluated as an "ancestral territory" or a "motherland" for the groups that arrived earlier.

The Meskhetian Turks were also unable to create any economic power in terms of capital ownership in the Meskhetian territories. Their forced displacement and the administrative pressure significantly destroyed their potential for becoming economic and political powers. Moreover the lack of sound policy by the Turkish government and weak lobbying activities does not provide a bilateral political climate to facilitate the return of the Meskhetian Turks remaining in Turkey to their settlement in Meskheti.

This underlines the fact that there is still no remedy for the majority of Meskhetian Turks other than returning to Turkey. According to both the respondents from the university youth in İzmir and the respondents living in different provinces, it can be stated that there is no interest in, or comprehensive information on, Meskhetian Turks in Turkey.

Immigrants coming to Turkey generally lack the capacity to create an economic field of employment. Likewise, the Meskhetian Turks who have immigrated to Turkey also work mostly in the administrative or bureaucratic mechanisms in the service sector. However in the context that Meskhetian Turks attach importance to education, it might be expected that they will become successful in different sectors in the future.

In Turkey, citizens treat the principles of equality within the law with respect. Their strong political and social preferences along with their disinclination to create a privileged environment for any ethnic group either in theory or in practice influence administrative decisions. Neither do Meskhetian Turks have a wish to create a distinct agenda on obtaining such a privilege.

Central Asia is evaluated as "the motherland" for the settled Turks in Turkey on the basis of history education in Turkey. Thus, Central Asia is only of emotional significance for most Turkish citizens. With a similar approach, Turkey will also be evaluated, two or three generations later, as the "homeland belonging" of the Meskhetian Turks who have adopted a settle life in Turkey, Such a transformation is expected to enhance the commonality of social trust by enabling the immigrants to understand and relate to each other easily resulting from their common Turkish origin.

This study covers the Meskhetian Turks' arrival in Turkey from various countries under the political pressures, through forced and mass immigration. Observations and the interviews during the study reflect the present situation. But it is hard to predict the future. This issue reveals the academic and social signific- 
ances of Mesketian Turks phenomenon. In time things will change: new migration routes and new targets will develop as a result of to global and political climatic pressure. We hope that no new tragic stories will emerge.

\section{Conflicts of Interest}

The authors declare no conflicts of interest regarding the publication of this paper.

\section{References}

[1] Aydıngün, A., Harding, Ç.B., Hoover, M., Kuznetsov, I. and Swerdlow, S. (2006) Meskhetian Turks: An Introduction to Their History, Culture and Resettlement Experiences. Center for Applied Linguistics, Washington DC.

[2] Mursül, D. (2018) Türkiye’ye Yerleşme Amacıyla Gelen Ahıska Türklerine Yönelik Göç Yönetimi Stratejisi. Nobel Akademik Yayıncılık, Ankara.

[3] Trier, T., Mouravi, G.T. and Kilimnik, F. (2011) Meskhetians: Homeward Bound. European Center for Minority Issues-Caucasus, Georgia.

[4] Aydıngün, A., Harding, Ç.B., Hoover, M., Kuznetsov, I. and Swerdlow, S. (2006) Meskhetian Turks: An Introduction to Their History, Culture and Resettlement Experiences. Center for Applied Linguistics, Washington DC.

[5] Bayraktar, R. (2013) Eski Sovyetlerde Türk Kimliği. Berikan Yayınevi, Ankara.

[6] Üren, M. (2016) Kimlik, Çıkar ve Jeopolitik Ekseninde Ahıska Türkleri Sorunu. Nobel Yayıncilık, Ankara.

[7] Kurt, S. (2017) Ahıska Türkleri ile Ahıska Yurdunun Türkiye için Önemi. Giresun Üniversitesi Íktisadi ve Ídari Bilimler Dergisi, 3, 95-119.

[8] Settlement Law No. 5543 (2006). http://www.mevzuat.gov.tr/MevzuatMetin/1.5.5543.pdf

[9] Karaman, Z.T. (2015) Perceptions of Immigrants by the Local People and Administrative Perspectives Regarding the Immigrants of Turkish Origin Who Came to Turkey from Bulgaria: A Case Study of Izmir. Open Journal of Social Sciences, 3, 5-22. https://doi.org/10.4236/jss.2015.312002

[10] Karaman, Z.T. (2012) An Empirical Study of the Effects of Social and Cultural Differences of Foreign Retired Residents on Local Citizens Around Antalya Area of Turkey. International Journal of Business and Social Science, 3. http://www.ijbssnet.com/journal/index/895.

[11] Karaman, Z.T. (2015) Perceptions of Immigrants by the Local People and Administrative Perspectives Regarding the Immigrants of Turkish Origin Who Came to Turkey from Bulgaria: A Case Study of Izmir. Open Journal of Social Sciences, 3, 5-22. https://doi.org/10.4236/jss.2015.312002

[12] Tomlinson, K. (2015) Meskhetian Turks: Displacement, Self-Perception and the Future. A Document of the Bridging Refugee Youth \& Children's Services Clearinghouse.

[13] Etherington, J.R. (2010) Nationalism, National Identity and Territory: Jacint Verdaguer and Catalan Renaixença. Ethnic and Racial Studies, 6.

https://hal.archives-ouvertes.fr/hal-00595189/document

[14] Aydıngün, A. and Aydıngün, İ. (2014) Ahıska Türkleri Ulusötesi Bir Topluluk Ulusötesi Aileler. Ahmet Yesevi Üniversitesi Yayınları, Ankara. 
[15] Bauman, Z. (1996) From Pilgrim to Tourist or a Short History of Identity. In: Hall, S. and Du Gay, P., Eds., Questions of Cultural Identity, London, 19-36. https://www.nyu.edu/classes/bkg/tourist/Baumann-pilgrim-tourist.pdf

[16] Karaman, Z.T., Özmen, Ö.N.T., Yontar, İ.G. and Özer, Y.E. (2013) Dış Göçler (İzmir'de Bulgaristan'dan Gelen Türk Soylu Göçmenler). Birleşik Matbaacılık, İzmir.

[17] Erdoğan, M. and Kaya, A. (2015) Türkiye'nin Göç Tarihi: 14. Yüzyıldan 21. Yüzyıla Türkiye’ye Göçler. İstanbul Bilgi Üniversitesi Yayını, İstanbul. https://file.scirp.org/pdf/JSS_2015120313233521.pdf

[18] Ünal, S. and Demir, G. (2009) Göç, Kimlik ve Aidiyet Bağlamında Türkiye'de Balkan Göçmenleri. VI. Ulusal Sosyoloji Kongresi: Toplumsal Dönüşümler ve Sosyolojik Yaklaşımlar Bildiri Kitabı, Adnan Menderes Üniversitesi. Aydın. 1-3 Ekim 2009, 379-407.

[19] Zeyrek, Y. (2011) Mustafa Abdülcemil Kırımoğlu ile Mülakat. Bizim Ahıska Dergisi. (21), 3-4.

[20] Pentikainen, O. and Trier, T. (2004) Between Integration and Resettlement: The Meskhetian Turks. European Centre For Minority Issues Working Paper No. 21, ECMI, Flensberg. 